Tomasz Rogoziński ${ }^{1}$

\title{
THE EVALUATION OF MICROFUNGAL CONTAMINATION OF DUST CREATED DURING WOODWORKING IN FURNITURE FACTORIES
}

\author{
OCENA ZANIECZYSZCZENIA MIKROGRZYBAMI PYŁU \\ POWSTAŁEGO PODCZAS OBRÓBKI DREWNA W FABRYKACH MEBLI
}

\author{
${ }^{1}$ Poznan University of Life Sciences / Uniwersytet Przyrodniczy w Poznaniu, Poznań, Poland \\ Department of Furniture Design / Katedra Meblarstwa \\ ${ }^{2}$ Poznan University of Life Sciences / Uniwersytet Przyrodniczy w Poznaniu, Poznań, Poland \\ Department of Chemistry / Katedra Chemii \\ ${ }^{3}$ Wood Technology Institute in Poznan / Instytut Technologii Drewna w Poznaniu, Poznań, Poland \\ ${ }^{4}$ Poznan University of Life Sciences / Uniwersytet Przyrodniczy w Poznaniu, Poznań, Poland \\ Department of Phytopathology, Seed Science and Technology / Katedra Fitopatologii i Nasiennictwa
}

\begin{abstract}
Background: Microscopic fungi are the biological agent of occupational risk in the woodworking environment. Microbiologi$\mathrm{cal}$ and chemical methods were used for determination of their concentration and species composition in dust. Material and Methods: Dust was sampled in 3 factories producing furniture using different materials. The 1st factory (A) processes solid wood, the 2 nd (B) - chipboards and the 3rd factory (C) uses both wood and wood composites. The samples were collected in 12 different workstations and locations in each factory. The quantitative content of fungal biomass was determined basing on analysis of ergosterol (ERG). The species composition of fungi was analyzed using the microbiological method basing on culture morphology. Results: The concentration of ergosterol was relatively low and ranged from $0.012 \mathrm{mg} / \mathrm{kg}$ to $3.36 \mathrm{mg} / \mathrm{kg}$. The average value of ERG amounted to $1.25 \mathrm{mg} / \mathrm{kg}$ in factories A and C and $1.15 \mathrm{mg} / \mathrm{kg}$ in factory B. The most frequently isolated fungi in factory A and B were Penicillum and Aspergillus. However, in the factory C, only Trichoderma was isolated. The maximum concentration of fungi in dust collected in factory B was $2377 \mathrm{cfu} / \mathrm{g}$ and it is 3 times more than in the dust from factories A and C. Conclusions: Workers of furniture factories may be exposed to airborne fungi associated with the wood dust posing health hazard. The content of these fungi is relatively small (ERG - max: $3.36 \mathrm{mg} / \mathrm{kg}$ ) but the species, especially genera Penicillum and Aspergillus, found in the dust which were reported as having allergic and toxic properties. Med Pr 2014;65(6):705-713
\end{abstract}

Key words: wood dust, ergosterol, fungi, occupational diseases, furniture factory

\section{STRESZCZENIE}

Wstęp: Mikroskopijne grzyby stanowią biologiczny czynnik ryzyka zawodowego w środowisku pracy przemysłu drzewnego. W badaniu w celu określenia ich stężenia i składu gatunkowego w pyle wykorzystano metodę mikrobiologiczną i chemiczną. Materiał i metody: Próbki pyłu pobierano w 3 wybranych zakładach produkujących meble z różnych materiałów. Pierwsza fabryka (A) przetwarzała lite drewno, druga (B) - płyty wiórowe, a trzecia (C) wykorzystywała do produkcji mebli zarówno drewno, jak i tworzywa drzewne. Próbki pobierano z 12 różnych stanowisk roboczych i innych miejsc w każdym z zakładów. Zawartość ilościową biomasy grzybowej oznaczono w oparciu o analizę ergosterolu (ERG). Analizę składu gatunkowego grzybów przeprowadzono, stosując metodę mikrobiologiczną, w której wykorzystywane są ich cechy morfologiczne. Wyniki: Stężenie ergosterolu było stosunkowo niskie i wynosiło od $0,012 \mathrm{mg} / \mathrm{kg}$ do $3,36 \mathrm{mg} / \mathrm{kg}$. Średnia wartość ERG wynosiła 1,25 mg/kg w zakładach A i C oraz $1,15 \mathrm{mg} / \mathrm{kg}$ w fabryce B. Grzybami najczęściej izolowanymi w fabrykach A i B były grzyby z rodzaju Penicillum i Aspergillus. W fabryce C wyizolowano tylko grzyby z rodzaju Trichoderma. Maksymalna zawartość biomasy grzybowej w próbce pyłu osiadłego pochodzącego z fabryki B wynosiła 2377 jtk/g i była 3 razy większa niż w pyle z fabryk A i C. Wnioski: Pracownicy fabryk mebli mogą być narażeni na ekspozycję na pył drzewny zawierający grzyby, które stwarzają zagrożenie dla ich zdrowia. Zawartość biomasy grzybowej była stosunkowo niska (ERG - maks.: 3,36 mg/kg), ale wykryto gatunki, szczególnie z rodzajów Penicillum i Aspergillus, które wykazują właściwości alergizujące i toksyczne. Med. Pr. 2014;65(6):705-713

Słowa kluczowe: pył drzewny, ergosterol, grzyby, choroby zawodowe, fabryka mebli

Corresponding author / Autor do korespondencji: Tomasz Rogoziński, Poznan University of Life Sciences, Department of Furniture Design, Wojska Polskiego 28, 60-637 Poznań, e-mail: trogoz@up.poznan.pl

Received: 2014, May 12, accepted: 2014, July 28 


\section{INTRODUCTION}

Mechanical processing of wood and wood materials is connected with producing large amounts of waste. The smallest of them - dust particles - present a great problem in the working environment. Kauppinen et al. (1) estimated that about 3.6 million woodworkers in 25 member states of the European Union are occupationally exposed to inhalation of wood dust. Dustiness of the air in woodworking rooms is a cause of many disadvantageous phenomena. Some difficulties have been observed in the running of woodworking machines, higher fire and explosion risks as well as adverse negative health effects in the workers employed in woodworking industries (2-5).

A number of species of microorganisms may naturally occur and grow on the stored logs, lumber and chipped wood or wood waste. Their solid parts and biologically active products are being aerosolized during machining and other operations, e.g. transport. This is why air dustiness is associated with the occurrence of fungal and bacterial microflora which is a potential health hazard for workers of wood industry.

Decrease in air quality on woodworking stations caused by dust particles dispersed in the air can be a reason of harmful diseases and health problems. Occupational exposure to wood dust connected with working in wood processing industry, including sawmills, fiberboard and chipboard factories and furniture production, may be a risk factor for sinus and nasal cancer and lung cancer. It may also cause asthma and cough symptoms, respiratory problems, such as allergic alveolitis and chronic bronchitis, along with the eye, nose and skin irritation (6,7). Jacobson et al. (8), on the basis of their literature review of associations between exposure to wood dust and respiratory diseases, stated that this exposure is a real risk factor for the development of asthma, rhino-conjunctivitis, chronic bronchitis, and the decrease of lung function, but the mechanisms are mostly unknown. There are exposures, such as airborne fungi, endotoxin and terpenes, which influence health hazards in the woodworking industry.

Reduced lung function and other respiratory symptoms can be directly induced by various factors. Bacterial endotoxins and mycotoxins can be mentioned among them. The occurrence of fungi and their biologically active products in the air in the industrial environment of wood processing industry factories, such as sawmills, furniture factories and fibreboard and chipboard factories, has been described in numerous studies. The content of this microbial biomass varies in individual facilities depending on the processed material (wood, boards) and the phase of the production cycle is correlated with the overall dust concentration in the air. In its presence, exposed workers develop increased susceptibility to allergic reactions and other respiratory diseases caused by microbial factors, especially some species of fungi (Aspergillus fumigatus, Penicillum spp., Cryptostroma corticale, rarely others) (9-11).

The airborne dust particles can deposit on all of the open surfaces inside the production rooms. Bacteria and fungi can also grow and develop in a layer of settled dust. This dust is often a source of secondary air pollution by microbial factors.

The aim of this work was to determine the concentration and identification of microscopic fungi in dust settled inside the production rooms of furniture factories using microbiological and chemical methods. Chemical analysis was based on the investigations of ergosterol content and this type of analysis has not yet been carried out in the furniture industry.

\section{MATERIAL AND METHODS}

Samples of dust were collected in 3 furniture factories which differed in the kind of working material used in the production process. In factory A, furniture elements were made from solid beech, oak and alder wood, in factory B, furniture was made from board materials, such as MDF and chipboards and, in factory $\mathrm{C}$ - both kinds of wood and boards were used for furniture production. The dust came from 12 selected, characteristic for furniture production, places in each factory (Table 1).

There were typical workstations in these factories. They were surfaces near woodworking machines, on the stored materials, on transporting ways and near the separating devices of dust exhausting systems. Due to the specific character of the investigations conducted, the surface of free settling could be neglected, while the weight of the settled dust was of greater importance for further analyses. The surfaces of the chosen places differed in the area due to various settling rates of dust. The area of dust sampling was relatively small, e.g., at a multi boring machine and large at timber storage. These were the technology surfaces not altered in any way for the planned tests. Exposure lasted for 7 consecutive working days. Dust samples were collected mechanically using a sterile spatula and placed in sterile sealed tubes. They were stored until the analysis in conditions of low temperature. The weight of 
Table 1. Location of sampling areas

Tabela 1. Lokalizacja powierzchni, z których pobrano próbki

\begin{tabular}{|c|c|c|c|}
\hline \multirow{2}{*}{$\begin{array}{l}\text { No. } \\
\mathrm{Nr}\end{array}$} & \multicolumn{3}{|c|}{$\begin{array}{l}\text { Factory - workstation or area } \\
\text { Fabryka - stanowisko robocze lub miejsce }\end{array}$} \\
\hline & A & B & $\mathrm{C}$ \\
\hline 2 & cross-cut saw / pilarka poprzeczna & $\begin{array}{l}\text { panel saw (area of workstation) / pilarka } \\
\text { formatowa (powierzchnia stanowiska) }\end{array}$ & circular saw machine / pilarka panelowa \\
\hline 3 & multi-rip saw / pilarka wielopiłowa & $\begin{array}{l}\text { chipboard storage area / miejsce } \\
\text { składowania płyt }\end{array}$ & $\begin{array}{l}\text { chipboard storage area / miejsce } \\
\text { składowania płyt }\end{array}$ \\
\hline 4 & $\begin{array}{l}\text { wood blanks storage place / miejsce } \\
\text { składowania fryzów }\end{array}$ & $\mathrm{CNC}$ router / centrum obróbkowe & panel saw / pilarka formatowa \\
\hline 5 & planer / wyrówniarka & $\begin{array}{l}\text { CNC router (area of workstation) / centrum } \\
\text { obróbkowe (powierzchnia stanowiska) }\end{array}$ & $\mathrm{CNC}$ router / centrum obróbkowe \\
\hline 7 & $\begin{array}{l}\text { spindle moulder / frezarka } \\
\text { dolnowrzecionowa }\end{array}$ & $\begin{array}{l}\text { edgebander (area of workstation) / } \\
\text { oklejarka (powierzchnia stanowiska) }\end{array}$ & $\begin{array}{l}\text { automatic boring machine / wiertarka } \\
\text { automatyczna }\end{array}$ \\
\hline 8 & circular saw machine / pilarka panelowa & $\begin{array}{l}\text { automatic boring machine / wiertarka } \\
\text { automatyczna }\end{array}$ & edgebander / oklejarka \\
\hline 9 & stroke sander / szlifierka taśmowa & $\begin{array}{l}\text { multi boring machine / wiertarka } \\
\text { wielowrzecionowa }\end{array}$ & $\begin{array}{l}\text { edgebander (area of workstation) / } \\
\text { oklejarka (powierzchnia stanowiska) }\end{array}$ \\
\hline 10 & disc sander / szlifierka tarczowa & robot packer / robot pakujący & stroke sander / szlifierka taśmowa \\
\hline 11 & $\begin{array}{l}\text { base of dust extractor fan / podstawa } \\
\text { wentylatora transportowego }\end{array}$ & $\begin{array}{l}\text { base of dust extractor fan / podstawa } \\
\text { wentylatora transportowego }\end{array}$ & $\begin{array}{l}\text { base of dust extractor fan / podstawa } \\
\text { wentylatora transportowego }\end{array}$ \\
\hline
\end{tabular}

A - factory producing furniture from solid wood / fabryka wytwarzająca meble $\mathrm{z}$ drewna litego, B - factory producing furniture from MDF and chipboards / fabryka wytwarzająca meble z płyt wiórowych i MDF, C - factory producing furniture from solid wood, MDF and chipboards / fabryka wytwarzająca meble z drewna litego, płyt wiórowych i MDF.

CNC - Computerized Numerical Control / komputerowe sterowanie urządzeniami numerycznymi, MDF - medium-density fibreboard / płyta pilśniowa średniej gęstości.

the collected dust was approximately $3-5 \mathrm{~g}$. The dust was collected in 3 replications in each place. A total number of 108 samples of dust were tested for the content of fungal biomass. The moisture content of dust was not measured due to the small weight of samples.

Quantitative determination of fungal biomass was done based on the chemical method of analysis of specific fungal marker, such as ergosterol. The scope of this work also included determining which fungal species occur in the analyzed dust. The analysis of species composition was done using the dilution method.

\section{Analysis of ergosterol}

Ergosterol extraction was performed based on the method by Lidia Szwajkowska-Michałek et al. (2010) (12). A $100 \mathrm{mg}$ sample was extracted with saponification by means of the microwave assisted extraction method using $2 \mathrm{M} \mathrm{NaOH}$. After neutralization, the samples were extracted with pentane ( 3 times; $4 \mathrm{ml}$ ). The ergosterol analysis was performed by a high-performance liquid chromatograph (Waters Corporation, Milford, MA, USA) with a UV detector $(\lambda=282 \mathrm{~nm})$. Quantitation was based on the external standard method. The limit of detection was $0.01 \mathrm{mg} / \mathrm{kg}$ (12).

\section{Analysis of fungi occurrence in dusts}

The analyses of the composition of viable fungi species occurring in average dusts' samples were done using the microbiological method. At the beginning of the analysis, $1 \mathrm{~g}$ of dust was placed in $10 \mathrm{ml}$ of sterile distilled water and mixed with a magnetic stirrer for $2 \mathrm{~min}$. Next, the $1 \mathrm{ml}$ of suspension was carried on the PDA medium 
(Potato-Dextrose Agar) in Petri dishes and spread with the aid of a sterile glass stick on the medium surface. The Petri dishes were incubated at $25^{\circ} \mathrm{C}$ for 7 days. Growing mycelia were isolated on the PDA and SNA (Syntetic Nutrient - Poor Agar) mediums.

Fungi were identified on the basis of culture morphology and sporulation on these specialist media using a microscope, based on the available mycological literature $(13,14)$. The concentration of fungi was expressed as colony forming units per gram of settled dust (cfu/g).

\section{RESULTS}

The results of the analysis of ergosterol in dust obtained from furniture production factories are shown in Figures 1-3.

In factory A (solid wood) higher content of ERG is present in the dust collected from the workstations than from the pre-treatment stations and the surfaces of timber storage as a raw material and a semi-finished product. Similarly high (more than $2 \mathrm{mg} / \mathrm{kg}$ ) content was

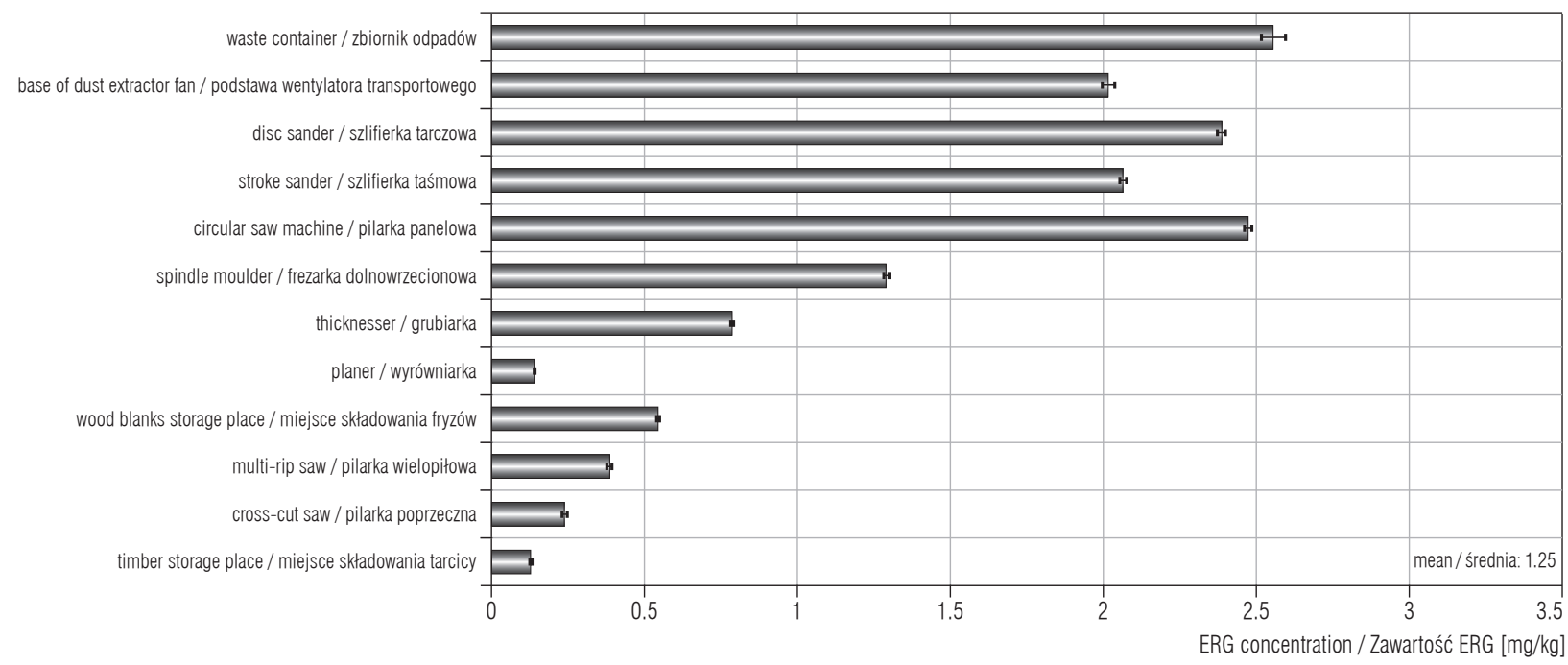

Fig. 1. Ergosterol (ERG) concentration in the samples $(\mathrm{N}=36)$ of dust coming from factory A - producing furniture from solid wood Ryc. 1. Zawartość ergosterolu $(E R G)$ w próbach $(\mathrm{N}=36)$ pyłu pochodzącego $\mathrm{z}$ fabryki $\mathrm{A}$ - wytwarzającej meble $\mathrm{z}$ drewna litego

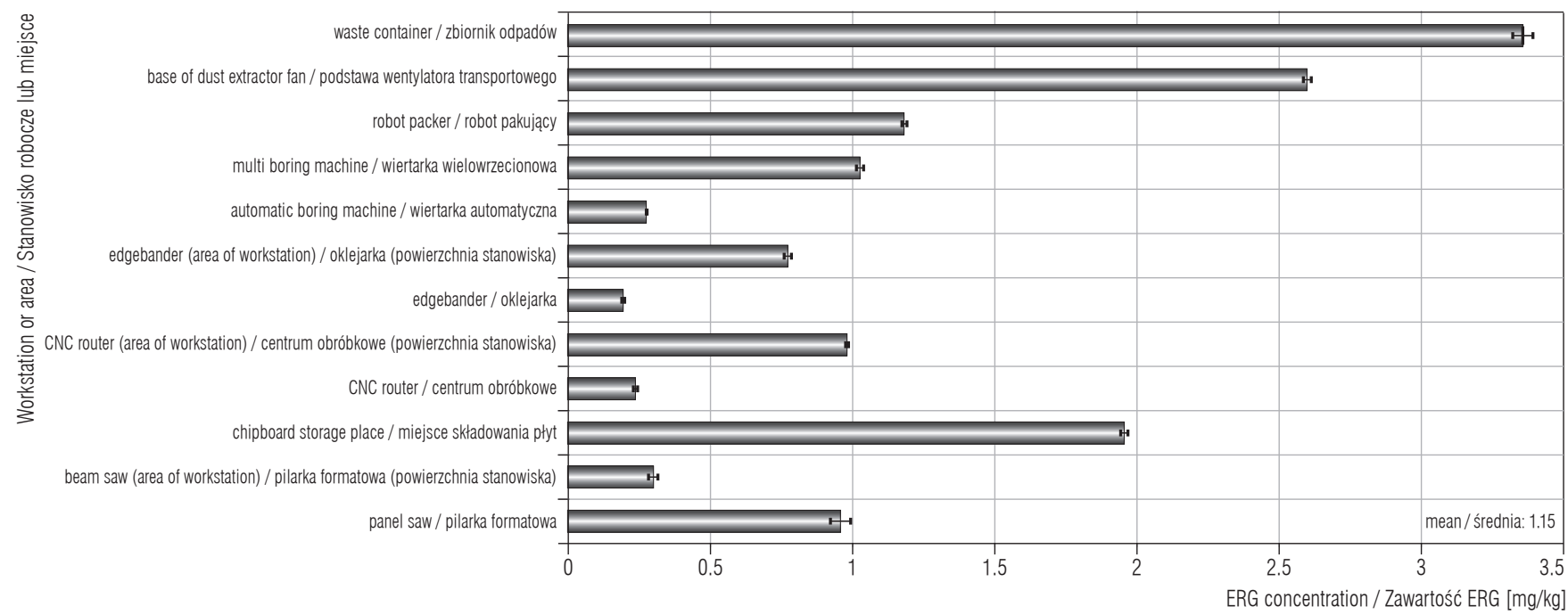

Fig. 2. Ergosterol (ERG) concentration in the samples $(\mathrm{N}=36)$ of dust coming from factory $\mathrm{B}$ - producing furniture from chipboards and medium-density fibreboard (MDF)

Ryc. 2. Zawartość ergosterolu (ERG) w próbach $(\mathrm{N}=36)$ pyłu pochodzącego z fabryki B - wytwarzającej meble z płyt wiórowych i płyt pilśniowych średniej gęstości (MDF) 


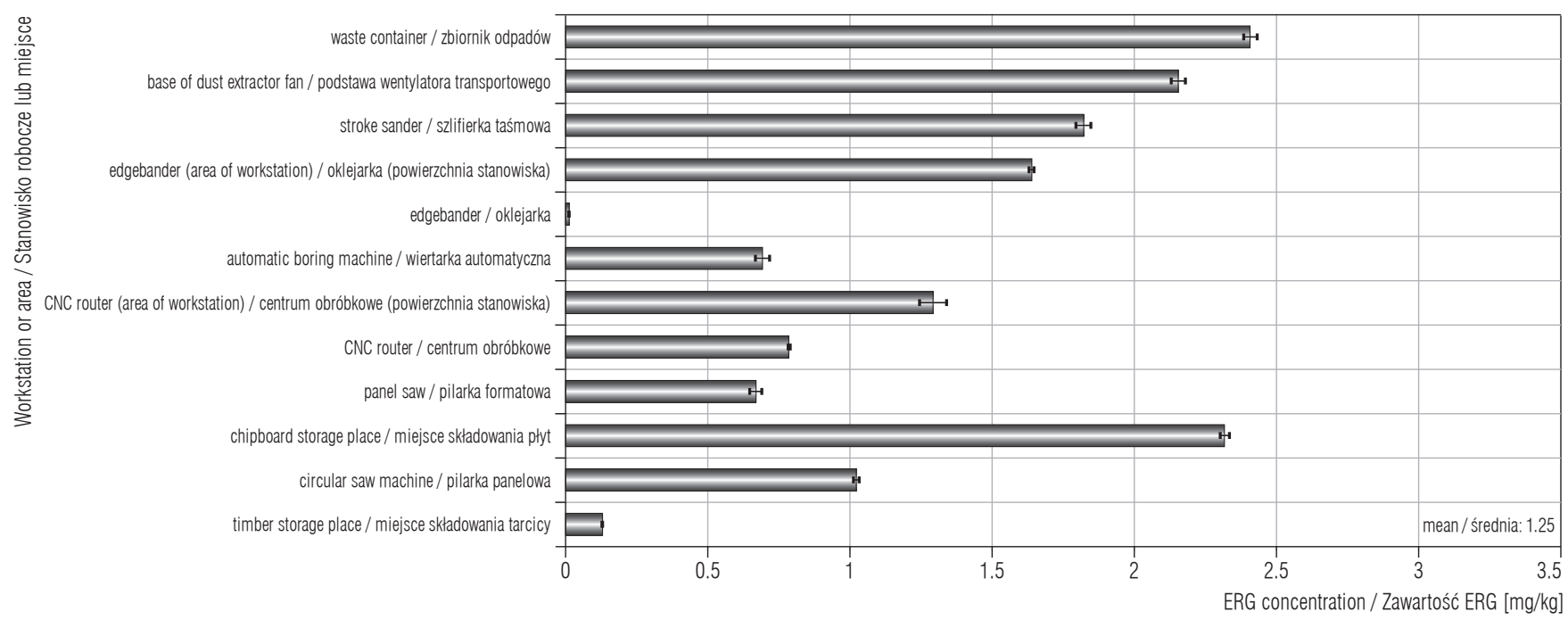

Fig. 3. Ergosterol (ERG) concentration in the samples $(\mathrm{N}=36)$ of dust coming from factory $\mathrm{C}$ - producing furniture from solid wood, chipboards and medium-density fibreboard (MDF)

Ryc. 3. Zawartość ergosterolu $(E R G)$ w próbach $(\mathrm{N}=36)$ pyłu pochodzącego z fabryki $\mathrm{C}$ - wytwarzającej meble z drewna litego, płyt wiórowych i płyt pilśniowych średniej gęstości (MDF)

found in the dust coming from the areas surrounding the end devices of the dust collection system (fans and dust containers). This can be regarded as the increase in the ERG content in dust from workstations of the later stages of the working process, where climatic conditions are different from pre-treatment. The time during which the worked material is in the factory also increases.

Fewer workstations from factory B were taken into account in the study due to the relatively simple technology of furniture making of chipboards. Dust samples were taken from various locations within the selected stations. The content of ERG in the settled dust in less accessible places has been found to be several times higher. It was particularly related to the most important working stations in this factory: panel saw machine, CNC machining centre, edgebander. The dust settled near the fan and the dust container installed in the dust extraction system are characterized by relatively high levels of ERG, in spite of the fact that these devices are located outside the building of the production hall.

In the case of the factory carrying out the manufacturing processes of furniture using both solid wood and wood-based materials, the most characteristic workstations of these processes were included in this study. These workstations are similar to those with which factories machining separately solid wood and chipboards are equipped. For this reason, there is a direct parallel between the workstations of factory $\mathrm{C}$ and positions selected in factories A and B. Therefore a direct comparison between them can be made. The dust settled on the timber storage area in factories $\mathrm{A}$ and $\mathrm{C}$ has a very similar content of ERG. In the storage area of chipboards in factory C, the ERG content is higher than in factory $\mathrm{B}$. The difference amounted here to $0.35 \mathrm{mg} / \mathrm{kg}$.

The results of the analysis of the species composition of fungi in average dust samples are given in Table 2. This analysis showed that the highest level of fungal contamination was found in a sample obtained from factory B. The cfu/g value here is approximately 2400 , about 3 times higher than in the dust samples from other factories. Moreover, the biggest differences occurred here, the dominant species being of the genera Penicillium, Aspergillus and Trichoderma. Similar proportions of these fungi are present in the dust from factory A, but here there are no fungi of the genera Alternaria, Bipolaris, Botrytis, Cladosporium and Paeciliomyces. It is associated with the overall lower content of the micoflora in the dust. The percentage of different genera of fungi was shown on Figures 4-5. They depict the proportions of fungi in the dust from factories $\mathrm{A}$ and $\mathrm{B}$. Factory $\mathrm{C}$ was not considered here because the whole isolated fungi belonged to only one genus - Trichoderma.

The highest frequency in the dust coming from the factory A was recorded for fungi from the genera Penicillium (54.25\%) and Aspergillus (23.10\%), while the lowest - for genus Mucor (2.76\%). The most frequently observed fungi in the dust from factory $\mathrm{B}$ were the genera Penicillium (40.85\%) and Aspergillus (23.47\%), too. The genera Alternaria and Bipolaris $(<2 \%)$ have been identified as the least represented in this factory. 
Table 2. Species composition of fungi in the investigated factories

Tabela 2. Obecność poszczególnych gatunków grzybów w badanych fabrykach mebli

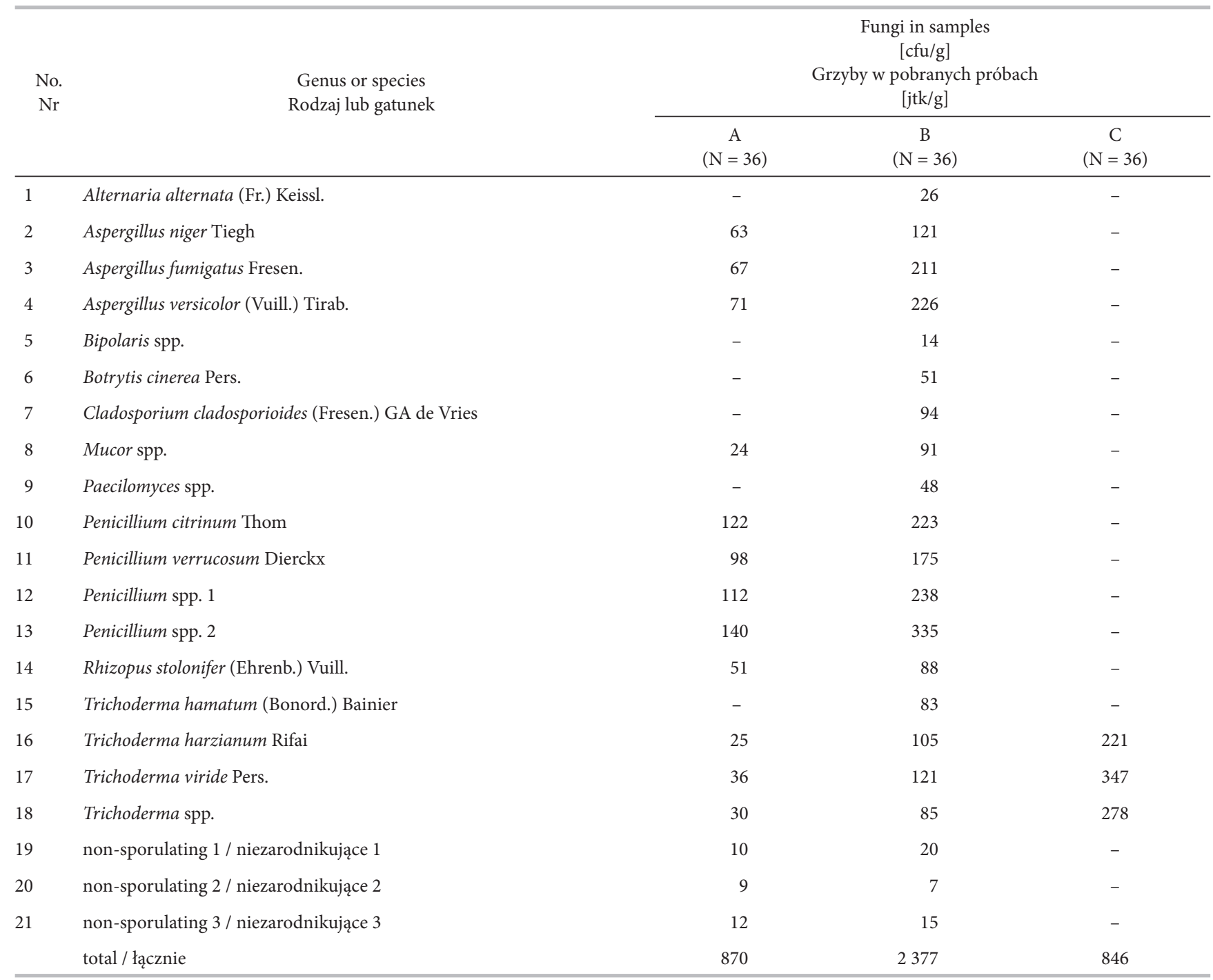

$\mathrm{N}$ - number of samples / liczba prób. Other abbreviations as in Table 1 / Inne skróty jak w tabeli 1.

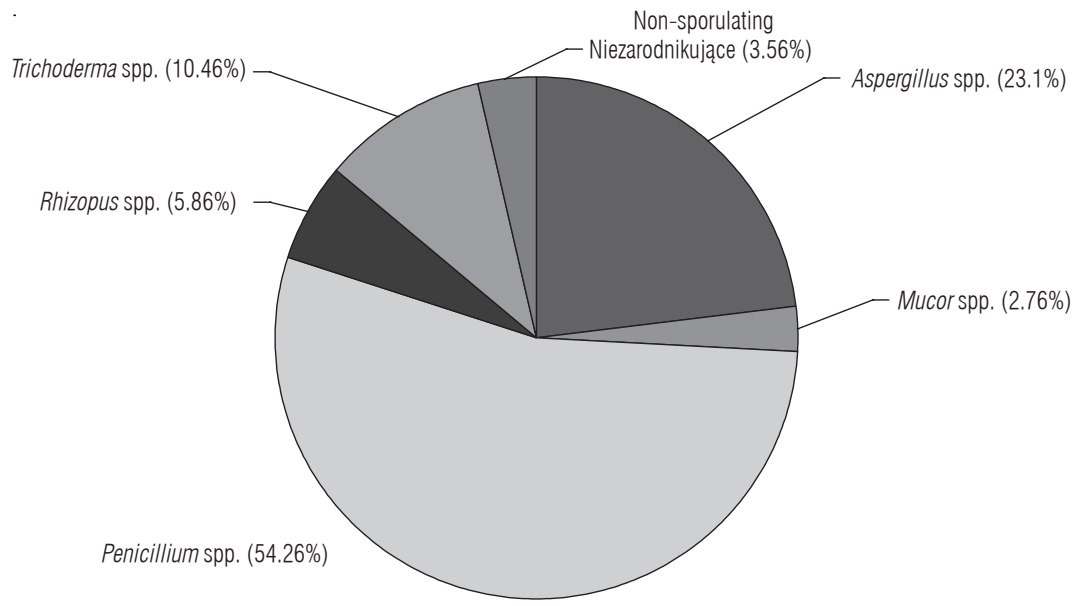

Fig. 4. Genera of fungi in the samples $(\mathrm{N}=36)$ of dust from factory $\mathrm{A}$ - producing furniture from solid wood

Ryc. 4. Skład rodzajowy grzybów w próbach $(\mathrm{N}=36)$ pyłu pochodzącego z fabryki A - wytwarzającej meble z drewna litego 


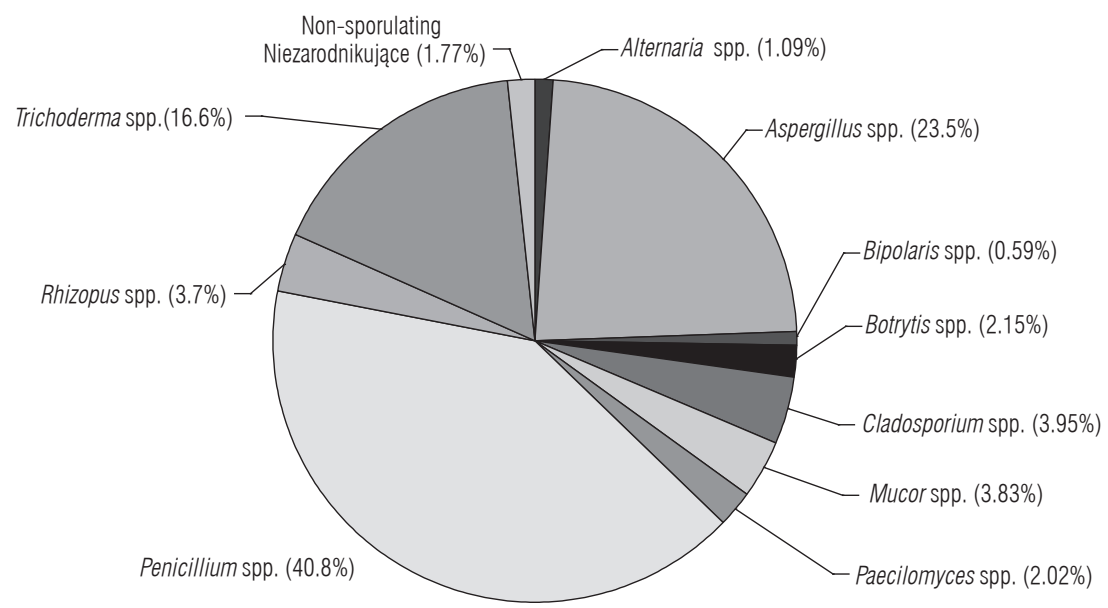

Fig. 5. Genera of fungi in the samples $(\mathrm{N}=36)$ of dust from factory $\mathrm{B}$ - producing furniture from chipboards and medium-density fibreboard (MDF)

Ryc. 5. Skład rodzajowy grzybów w próbach $(\mathrm{N}=36)$ pyłu pochodzącego z fabryki B - wytwarzającej meble z płyt wiórowych i płyt pilśniowych średniej gęstości (MDF )

\section{DISCUSSION}

In general, it can be said that the content of ERG is very low in comparison with the dust of different origin contaminating the work environment and other places where people live. In some works, the authors presented values reaching tens of $\mathrm{mg} / \mathrm{kg}$ and, in extreme cases, even more than $200 \mathrm{mg} / \mathrm{kg}$ (12). These works focused on the analysis of samples of plant origin, such as cereals. There is no comparative data in the literature available on ERG content in wood dust, especially from furniture factories. Such a low level of ERG content in analyses of the dust is undoubtedly related to the overall low content of fungal microflora in the air inside furniture factories and other institutions related to wood working and wood materials. In some studies on the effects of occupational exposure to the air containing microorganisms' levels of fungi that cause the risk of respiratory diseases, allergies, etc. were found relatively low or dropped during further stages of production processes $(15,16)$. Despite this, it is possible to notice a variation in the obtained contents of ERG depending on the type of the technological processes carried out in the factories and their stage.

A species composition similar to the one recorded in this study was given by various authors in the studies on the content of fungi associated with wood dust in the air of woodworking factories. Dutkiewicz et al. (17) indicated several species of fungi contaminating chipboard and fibreboard factories. They are Alternaria alternata, Aspergillus fumigatus, Aspergillus niger, Aspergillus repens, Candida spp., Cladosporium brevi-compactum, Geotrichum candidum, Mucor spp.,
Paecilomyces spp., Penicillium citrinum, Penicillium spp., Rhizopus nigricans, Rhodotorula graminis, Trichoderma album, Trichoderma viride, Trichothecium roseum. Among these species, the most important in this respect are Penicilium and Aspergillus. It is confirmed by quantitative data.

Krysińska-Traczyk et al. (16) identified mainly fungi from genera Aspergillus spp. including Aspergillus fumigatus, Penicillium spp., Absidia spp. in the air of factories making furniture from different materials (beech wood, fibreboards chipboards). Hameed et al. (18) have tested airborne dust bioaerosols in 2 different wood working factories. It turned out that the fungi of the genera Penicillium, Aspergillus, Cladosporium dominated among fungal isolates. Among the fungi contaminating the air in 6 different Italian woodworking factories, Gioffrè et al. (19) mentioned also Alternaria alternata, Aspergillus versicolor, A. niger, Cladosporium spp., Rhizopus spp., Mucor spp., Bipolaris spp., Trichoderma spp. Very high frequency of airborne fungi Penicillium spp., Cladosporium spp., Aspergillus spp., and Crysonillia sitophila was described by Šegvić Klarić et al. (20) for Croatian sawmills processing beech and oak wood. Nevertheless, according to other authors dealing with this problem, the most frequently isolated fungi from the air of wooden panel producing factory were Paecilomyces puntonii, Rhizopus nodosus and R. stolonifer (21).

The relatively high content of Penicillium and Aspergillus in the tested dust is thus similar to the most recent reports indicating their dominating frequency in the dust contaminating the air in the woodworking industry. This is especially important because fungi of the 
Penicillium spp. and Aspergillus spp. genera are ascribed to the common cause of work-related health diseases $(22,23)$.

To some extent, a surprising result was given by the analysis of the dust sample from factory $\mathrm{C}$ since only fungi of the Trichoderma genus have been isolated. It can be explained by its antagonistic effects on other species of fungi. This interaction is the inhibition of the growth of other species. This type of interaction between fungi of such genus as Trichoderma, Penicillium and others were already described in the literature $(24,25)$. The effect of this interaction would be in this case particularly strong due to the high content of fungi Trichoderma $-846 \mathrm{cfu} / \mathrm{g}$. It is two times more than in the dust samples from factory B and almost 10 times more than in the sample from factory $\mathrm{A}$.

\section{CONCLUSIONS}

Although the content of the fungal microflora in the dust coming from various positions connected with the processing of wood and wood-based materials in the studied factories is relatively small, and in some cases, even minimal, there may be a risk of occupational diseases, with respect to which species of fungi occur in the dust. Consequently, the problem of reducing dust emissions generated during the machining operations in the woodworking industry is still a vital issue. It is therefore strongly recommended to limit its formation using all possible ways, take care of the proper efficiency of the exhaust system which prevents the dustiness of the air in factories and dust settling on the surfaces there.

\section{REFERENCES}

1. Kauppinen T, Vincent R, Liukkonen T, Grzebyk M, Kauppinen A, Welling I, et al. Occupational exposure to inhalable wood dust in the member states of the European Union. Ann Occup Hyg. 2006;50(6):549-61, http://dx.doi.org/10.1093/annhyg/mel013.

2. Baran S, Teul I. Wood dust: An occupational hazard which increases the risk of respiratory disease. J Physiol Pharmacol. 2007;58 Suppl 5:43-50.

3. Chung KYK, Cuthbert JR, Revell GS, Wassel SG, Summers N. A study on dust emission, particle size distribution and formaldehyde concentration during machining of medium density fibreboard. Ann Occup Hyg. 2000;44(6): 455-66, http://dx.doi.org/10.1093/annhyg/44.6.455.

4. Palmqvist J, Gustafsson SI. Emission of dust in planning and milling of wood. Holz Roh-Werksttoff. 1999;
57(3):164-70, http://dx.doi.org/10.1016/S0003-4878(00)0 0005-3.

5. Scheeper B, Kromhout H, Boleij JSM. Wood-dust exposure during wood-working processes. Ann Occup Hyg. 1995;39(2):141-54, http://dx.doi.org/10.1093/ann hyg/39.2.141.

6. Barcenas CH, Delclos GL, El-Zein R, Tortolero-Luna G, Whithehead LW, Spitz MR. Wood dust exposure and the association with lung cancer risk. Am J Ind Med. 2005;47(4):349-57, http://dx.doi.org/10.1002/ajim.20137.

7. Douwes J, McLean D, Slater T, Pearce N. Asthma and other respiratory symptoms in New Zealand pine processing sawmill workers. Am J Ind Med. 2001;39(6):608-15, http://dx.doi.org/10.1002/ajim.1060.

8. Jacobsen G, Schaumburg I, Sigsgaard T, Schlunssen V. Non-malignant respiratory diseases and occupational exposure to wood dust. Part I. Fresh wood and mixed wood industry. Ann Agric Environ Med. 2010;17(1):15-28.

9. Dennekamp M, Demers PA, Bartlett K, Davies H, Teschke K. Endotoxin exposure among softwood lumber mill workers in the Canadian province of British Columbia. Ann Agric Environ Med. 1999;6(2):141-6.

10. Dutkiewicz J, Skórska C, Dutkiewicz E, Matuszyk A, Sitkowska J, Krysińska-Traczyk E. Response of sawmill workers to work-related airborne allergens. Ann Agric Environ Med. 2001;8(1):81-90.

11. Skórska C, Krysińska-Traczyk E, Milanowski JJ, Cholewa G, Sitkowska J, Góra A, Dutkiewicz J. Response of furniture factory workers to work-related airborne allergens. Ann Agric Environ Med. 2002;9(1):91-7.

12. Szwajkowska-Michałek L, Stuper K, Lakomy P, Matysiak A, Perkowski J. Contents of microscopic fungi in dusts coming from cereal analysis laboratories. Ann Agric Environ Med. 2010;17(1):101-6.

13. Raper KB, Thom C. A manual of the Penicillia. Baltimore: Williams \& Wilkins; 1949.

14. von Arx JA. The genera of fungi sporulating in pure culture. Germany: Lehre Verlag von J. Cramer; 1970.

15. Dutkiewicz J, Olenchock SA, Krysińska-Traczyk E, Skórska C, Sitkowska J, Prazmo Z. Exposure to airborne microorganisms in fibreboard and chipboard factories. Ann Agric Environ Med. 2001;8(2):191-9.

16. Krysińska-Traczyk E, Skórska C, Cholewa G, Sitkowska J, Milanowski J, Dutkiewicz J. Exposure to airborne microorganisms in furniture factories. Ann Agric Environ Med. 2002;9(1):85-90.

17. Dutkiewicz J, Krysińska-Traczyk E, Prazmo Z, Skórska C, Sitkowska J. Exposure to airborne microorganisms in Polish sawmills. Ann Agric Environ Med. 2001; 8(1):71-80. 
18. Abdel Hameed AA, Khoder MI, Farag SA. Organic dust and gaseous contaminants at wood working shops. J Environ Monit. 2000;2:73-6, http://dx.doi.org/10.1039/ a907102d.

19. Gioffrè A, Marramao A, Ianno A. Airborne microorganisms, endotoxin, and dust concentration in wood factories in Italy. Ann Occup Hyg. 2012;56(2):161-9, http://dx.doi.org/10.1093/annhyg/mer082.

20. Šegvić Klarić M, Varnai VM, Ljubičić Čalušić A, Macan J. Occupational exposure to airborne fungi in two Croatian sawmills and atopy in exposed workers. Ann Agric Environ Med. 2012;19(2):213-19.

21. Lugauskas A, Krikstaponis A, Sveistyte L. Airborne fungi in industrial environments - Potential agents of respiratory diseases. Ann Agric Environ Med. 2004;11(1):19-25.
22. Dutkiewicz J, Prażmo Z. [Occupational biohazards in wood industry]. Zdr Publ. 2008;118(2):138-44. Polish.

23. Wiszniewska M, Walusiak J, Gutarowska B, Żakowska Z, Pałczyński C. [Moulds - occupational and environmental hazards]. Med Pr. 2004;55(3):257-66. Polish.

24. Cuervo-Parra JA, Ramirez-Suero M, Sánchez-López V, Ramirez-Lepe M. Antagonistic effect of Trichoderma harzianum VSL291 on phytopathogenic fungi isolated from cocoa (Theobroma cacao L.) fruits. Afr J Biotechnol. 2011;10(52):10657-63.

25. Harman GE. Overview of mechanisms and uses of Trichoderma spp. Phytophatology. 2006;96(2):190-4, http://dx.doi.org/10.1094/PHYTO-96-0190.

The use of the article "The evaluation of microfungal contamination of dust created during woodworking in furniture factories" is permitted under license conditions of Creative Commons Attribution-NonCommercial 3.0 (also known as CC-BY-NC), available at http://creativecommons.org/licenses/ by-nc/3.0/pl/ or another language version of this license or any later version of this license published by Creative Commons / Zezwala się na korzystanie z artykułu „Ocena zanieczyszczenia mikrogrzybami pyłu powstałego podczas obróbki drewna w fabrykach mebli” na warunkach licencji Creative Commons Uznanie autorstwa - Użycie niekomercyjne 3.0 (znanej również jako CC-BY-NC), dostępnej pod adresem http://creativecommons.org/licenses/ by-nc/3.0/pl/ lub innej wersji językowej tej licencji, lub którejkolwiek późniejszej wersji tej licencji, opublikowanej przez organizację Creative Commons. 